\section{Lesibana Rafapa}

Lesibana Rafapa (Ph.D, University of Stellenbosch) teaches in the English Department of the University of Venda, Thohoyandou. His book-length critical texts include The Representation of African Humanism in the Narrative Writings of Es'kia Mphahlele (Stainbank \& Associates, 2006) and Es'kia Mphahlele's Afrikan Humanism (Stainbank \& Associates, forthcoming). He has also published eight novels in Northern Sotho. E-mail: rafapalj@univen.ac.za

\section{Es'kia Mphahlele's etching of two axes of religion using the frame- work of his concept of Afrikan Humanism in Father Come Home}

\title{
Es'kia Mphahlele's etching of two axes of religion using the framework of his concept of Afrikan Humanism in Father Come Home
}

This article looks at Mphahlele's application of his theory of Afrikan Humanism in his novel Father Come Home (1984). Since he regards religion as pervasive in the life of Africans, the novel is analysed from a religious perspective. The aim is to highlight the consciousness crossroads faced by the postcolonial African as portrayed in the book. It is proposed that a prior study of Mphahlele's concept of Afrikan Humanism shall reveal more meaning in his fictional writings, as well as in the fiction of other postcolonial Africanist writers. Key words: Afrikan Humanism, postcoloniality, African religion, consciousness.

\section{Introduction}

As a postcolonial writer, Mphahlele appears to play a significant role in demonstrating that the distinctive identity of Africans as a broad cultural cluster, encompassing even those of the diaspora, continues in fundamental ways to preserve itself in the same way it did on a world scale in prehistoric times, through the Renaissance, through Enlightenment and through the European "scramble for Africa"; and on the South African terrain through detribalising threats of the 1950s when mass urban influx started to be a remarkable feature of society. The postcolonial theorist Edward Said reveals his appreciation of such a cultural role in the following way:

It has been the substantial achievement of all of the intellectuals [...] by their historical, interpretive, and analytic efforts to have identified the culture of resistance as a cultural enterprise possessing a long tradition of integrity and power in its own right, one not simply grasped as a belated reactive response to Western imperialism. (Said 1990: 73)

According to Bill Ashcroft, Gareth Griffiths and Helen Tiffin (1989: 2), postcolonial writing is the collective noun used to refer to whatever national literatures have emerged in their present form out of the experience of colonisation and have asserted themselves by "foregrounding the tension with the imperial power, and by emphasising their difference from the assumptions of the imperial centre." What Ashcroft et 
al do not acknowledge explicitly is that the "experience of colonization" does not end in "foregrounding the tension with the imperial power" where the only "centre" is the European imperial one. It continues beyond the political liberation of the colonised, where postcolonial writers still challenge iniquitous outlooks and practices of "centres" other than the western metropolitan one, because, congruously with postcolonial discourse, the world never had only one "centre" although at some stage the European imperial one was the most egregious. For example, Partha Chatterjee (1993) explicates other "centres" within the Bengali society that are both religiously and politically constituted by Bengali oppressors. Any postcolonial Bengali writer thus has to continue and challenge hegemony despite the formal demise of British colonisation more than a century ago. I use the term "postcolonial" in its accommodation of non-linear notions of time as well as differentiation among various social strata within nations in the way some Africanists such as Frantz Fanon (1963: 169) tailored it to have a meaning that is not indistinct or vague, to refer to any writing that strove to ameliorate the smothering effect of European inter-oppression and imperialism as well as intra-oppression and intra-imperialism among the oppressed, whether before or after the oppressed were politically freed. Before Ashcroft et al (1989) could define postcolonialism as they do from a Eurocentric perspective that homogenises the subaltern, Africanists such as Mphahlele were already engaged in the postcolonial enterprise manifested in coalescing his de-colonising theory of Afrikan Humanism. ${ }^{1}$ That is why in my analysis of Mphahlele's concept of Afrikan Humanism, I lean also on alternative perspectives on postcolonialism as theorised by writers such as Fanon (1963), Said (1990) and Ania Loomba (1998).

Mphahlele's Pan Africanist writing career started in South Africa in the 1940s when, inter alia, he published the collection of short stories Man Must Live and Other Stories (1946), long before the formal political freedoms of some African states and that of South Africa attained much later in 1994, yet his writings chafed against colonialism/apartheid to no lesser extent than those writers who might have started critiquing colonialism in retrospect after its demise. On the germination of Mphahlele's Afrikan Humanist theoretical project that embeds the dialectics of religion within the African psyche, (Obee 1999: 193) remarks that Mphahlele's style in Man Must Live and Other Stories (1946) "inventively" uses a worldview informed with the symbols, folklore, myth and imagery of a black aesthetic." More importantly, Mphahlele's writing continues beyond the 1950 and 1960s after black nationalist regimes had toppled European rule in a number of African states, this time being postcolonial in the sense of cautioning against and lambasting neo-colonial tendencies in such African governments. An example is the 1960 essay "Nigeria on the eve of independence" (Mphahlele 2004) in which he criticizes tribalistic and caste schisms within independent Nigeria's ruling elite and polity. In the novel, a case in point is the way he castigates apartheid in The Wanderers (1967) and satirises gluttonous neo-colonialism in Chirun- 
$d u$ (1967). David Attwell (1999: 70) alludes to the handiness of the Afrikan Humanist tool, including spiritual faith, in referring to The Wanderers as "organized around the development of Tabane's consciousness as he comes to terms with exile." Ruth Obee (1999: 174) implicitly refers to traditional African religion in the observation that "[b]ecause of the courage and integrity with which Tirenje adapts to modern ways while not losing her fundamental values and dignity, we are outraged by the crass manner in which she is wronged and exploited by the power-hungry Chirundu" (emphasis added). It should be borne in mind that self-declared power that does not result from reward by the people themselves for selfless service to the community is out of step with Afrikan Humanist tenets of social African hierarchical promotion, as Obee (1999: 191) herself concedes.

Obee (1999) falls short of declaring, as Lesibana Rafapa (2006) does, that the characterisation of Tirenje in Chirundu exemplifies Mphahlele's Afrikan Humanist religious regard for human life as sacred and spiritual orientation for women to be mystically regarded as seats and symbols of a people's adaptive cultural continuity and preservation. That is why in his 1987 essay "Social work and the politics of dispossession", Mphahlele highlights the socially sacred place of women among African cultural groups thus: "Marriage, the bride price, succession and inheritance, residence, erection of a place of abode, ancestral rituals related to the fertility of the soil and woman - all these and other activities are part of the rhythm of life. It is a rhythm controlled by the Life Force or Vital Force that has established a chain linking all beings" (Mphahlele 2002: 240). It is Mphahlele's foregrounding of African spirituality within the bigger canvas of Afrikan Humanism that, advertently or inadvertently, leads Obee (1999: 181) to evaluate Chirund $u$ as an original thematic invention in African writing which projects that "the new thematic arena of alienation and conflict many not be racial at all" and may prove to be "gender-based." The detracting factor in Obee's incisive analysis of Afrikan Humanism is her overstretching such religiously-inspired "gender-based" African attitude to invoke western feminist theory that, to my mind often conflates the fact that some African societies are patriarchal with the stereotype that African cultures are inherently paternalistic.

In the South African sphere, Mphahlele's postolonial concerns do not only end in pre-independence fiction such as Down Second Avenue (1959) in which the pernicious effects of apartheid among blacks is depicted ebulliently alongside the profiling of a consciousness and way of life he has called Afrikan Humanism. Negation of mimicry in the religious sphere is evident as illustrated in Down Second Avenue in the depiction of Mphahlele's maternal grandmother. The grandmother bans the children from being in the Marabastad streets after dark unless they go to evening church service (Mphahlele 1959: 78). The social sanction prevailing here is an Afrikan Humanist one of respect for the ancestors, as the sacrosanct reason she advances for this family rule is simply that it was their late grandfather's law before he died. The grandmother 
punctuates her earnest talk throughout Down Second Avenue with the phrase "as sure as Titus sleeps in his grave", thus invoking the continued presence of the departed in the affairs of the family. The social attribute of letting the ancestors remain part of the family is a feature of African religion (see Kudadjie and Osei 1988: 40) and expressive of the Afrikan Humanist ability to continue to honour and evoke elders even after they have passed away, a practice Mphahlele evidently treasures.

The older Mphahlele, free of grandmother's stern parental control, later takes advantage of the proliferation of breakaway African churches in Marabastad and starts roaming from one denomination to the other on different Sundays. When after such exploits he relates to his grandmother how an A.M. E. pastor amusingly mixes English and Sotho in his sermons, the grandmother retorts that one day the pastor will face retribution when his ancestors descend upon him and ask him where he has thrown his mother tongue (Mphahlele 1959: 99). Though a devout Christian and despite the above conversation relating to the action of a Christian preacher that takes place in a Christian church building, Grandma can still not think in terms of moral judgement without making reference to the superior guardianship of the ancestors rather than punishment in hell. The irony of such utterances by Grandma lies in the dogmatic forbidding of "ancestor worship" within the Christian church establishment. By means of dialogue such as Grandma's, Mphahlele wants to show that Afrikan Humanist belief in the ubiquitous presence of ancestral spirits among the lives of the living persists in the face of a modernisation process that seeks to outlaw it. Although Grandma is a devout Christian affiliated to the Methodist Church (Woeber 2001: 60), typical of Afrikan Humanist double-consciousness she cannot be wrested from the traditional African belief in ancestors, which Mphahlele regards as a building block of the concept of Afrikan Humanism.

If the apparent divergence of world views in the two sections of the Maupaneng community as well as apparently firm western Christianity in the urban characters like the grandmother were not relatively superficial, African values like respect for ancestors and perception of the Supreme Being in things like a piece of ground would not be portrayed in the autobiography. It is clear that beneath the apparent cultural-religious heterogeneity there is an underlying homogeneity.

With the teenager Mphahlele living on the "Christian" side of the Maupaneng village, he is among those fed on stories depicting the "heathens" as witches with whose footprints and shadows one had to avoid contact. Boys being boys, Eseki and his fellow goatherds and cattleherds constantly cross over to the "heathen" side, where one day they even naughtily explore the taste of baboon meat at the communal fireplace. The remarkable fact is that the boys are received warmly. The warm hospitality of the traditionalist section of the Maupaneng community evinces a conviction of affinity that defies the supposedly insurmountable differences between the two sections. What comes to the fore here is that two axis of religion, one African tradition- 
al and the other western Christian, intersect in the consciousness and lifestyle of African characters in Mphahlele's narrative writings. Because religion is pervasive in the life of Africans and not confined to some periods or days of the week like Sunday, such ambivalent religion characterising Mphahlele's African characters could as well be declared to be as significant as the Afrikan Humanist outlook in its totality.

It is this consolidation of an Afrikan Humanist ethos in Down Second Avenue which Obee (1999: 193) refers to as Mphahlele's "monumental work of criticism['s] [...] most communal expression as lived experience." Evidence of communalism in this 1959 novel is an aspect of what is now known as Mphahlele's concept of Afrikan Humanism. His post-1994 expository writing rails against frailties such as tribalism, comprador neo-colonialism and the excesses of capitalist elitism as vehemently as he did against earlier colonial regimes. This is evident in essays like those he first published in 1996 "What's new in the New South Africa" and "Face the truth about the spectre of tribalism" (see Mphahlele 2002) in which he pinpoints the pitfalls of praxis within ANC-led theoretically democratic government. In this way, I use the postcolonial ideals expressed by a writer before political freedom as well as such a writer's views on how freedom that is broader than mere political liberation can continue to be pursued beyond overt western colonisation as defining features of a postcolonial writer.

Such application of the term "postcolonialism" to Mphahlele's theoretical and fictive output does not conflict with notions of postcolonialism associated with writers such as Loomba (1998: 8), as a term that "is not only inadequate to the task of defining contemporary realities in the once-colonised, and vague in terms of indicating a specific period of history", but also as inclined to "cloud the internal social and racial differences in many societies." While I agree with this view of the term, neither do I find it dissonant with Mphahlele's view of postcoloniality, as his oeuvre demonstrates in its emphasis of dynamic process rather than reified event as well as on the primacy of localised differences while at the same time striving to find interconnecting strings that enable one broadly to refer to resistance by heterogeneous nationalities, classes, or races in clearly defined terms as postcolonial. Obee (1999: 189) testifies to Mphahlele's "ethos that binds African cultures regardless of locale or ethnicity" in his writings as an aspect of Afrikan Humanism. My position is that, evading to define postcoloniality in clear Eurocentric temporal terms of time as linear in chronology is shying away from the imperative of rigorous discussion of phenomena, and does not serve positively to refine intellectual debate - as squarely admitting the convenience of doing so while at the same time broadening such references with Africanist views of viewing time in relation to contingent dynamics of society.

Mphahlele's 1984 autobiography, Afrika My Music, is described by Obee (1999: 178) as "a philosophic and educational" ground-breaker, "viewed from the dialogic frame of themes of alienation and African humanism as they affect the formulation of a new 
South Africa." In other words, Afrikan Humanism is postulated as an antidote against apartheid-inflicted alienation. One pillar on which this antithesis of colonial alienation balances is again displayed by surviving African traditional religious orientation even among sophisticated exiles who belong to various western Christian denominations. Mphahlele epitomises this in his reverence of the departed. Such a survival of Afrikan Humanist traditional religion within the older Mphahlele takes on a more profound intensity in Afrika My Music than in earlier Down Second Avenue. The stylistic aspect of talking directly to the dead in supplicating fashion emerges with authorial maturity in Afrika My Music, in instances such as: "You pulled the strands together in Drum, Can" (Mphahlele 1984a: 123) where the narrator addresses his former colleague Can Themba (now dead). Again, thinking about the Drum years while in Denver, Colorado, Mphahlele addresses the late Gwigwi Mrwebi directly: "You used to say to me, Kyk hierso, nefie, you'd say, jy's a teacher nie a reporter nie" (Mphahlele 1984a: 124). But more importantly, the way Africans interpret death is supportive of the survivalist aspect of Afrikan Humanism that stresses continuity of individual and community life beyond death, as the following description of Aunt Dora's burial service illustrates:

Khabi and I had to leave for Pretoria where [Aunt Dora] was to be buried. I had failed to see her alive but the occasion gave me a chance to see old acquaintances and visit family graves. In the lengthy funeral rituals that followed, I was back in the rhetoric of death-and-life during the nights of the wake: words, words, words, poetry as ritual, ritual as poetry, death as the poetry of life, life as the poetry of death [...] That is how the Black man can soak himself in grief, until he can endure the sense of loss and its pain and not break. (Mphahlele in Manganyi 1983: 21, emphasis added)

In writing his 1984 short novel Father Come Home, Mphahlele avowedly sets out to affirm by means of fiction the fact that the kind of rural, undislocated African cultural identity is still liveable (Samin 1998: 194) today. This is the kind of African cultural life that could be found among his people of Maupaneng in his pre-pubescent years while he stayed with his paternal grandmother, before being moved to urban Marabastad in the 1930s. This is because, in his reasoning, African identity includes a lifestyle that is in rhythm with the self-assured serenity and dynamic traditionalism of rural life. The novel may be set in the rural past, but the memory it evokes is crucial in the on-going attempts of theories like his to make sure that African identity continues today not to be effaced by modern-day threats such as a globalism that disregards the different consciousnesses which varying peoples bring along to the global village.

The distinctive African identity that is the central focus of Mphahlele's theory of Afrikan Humanism faced many imperialist threats against its preservation in the past through colonisation and apartheid, yet survived. His concept of Afrikan Humanism 
dialectically drew on the heritage of $20^{\text {th }}$ century Pan Africanism and Black Consciousness ideologies of the 1930s and 1940s, as well as later debates among Africanist theorists on issues of essentialism, racism, ethnocentrism and monocentrism (Rafapa 2006). Mphahlele regards cultural resilience and a forward-looking hopefulness about collective cultural survival of distinctive Africanness to be an aspect of his theory of Afrikan Humanism. Though in a non-essentialist way but in ways bearing testimony to separate historico-geographic experiences between Europeans and Africans, Mphahlele regards the consciousness and lifestyle he defines as Afrikan Humanism culturally to distinguish Africans from non-Africans.

By the same token, Christianity and traditional conceptions of spirituality are mutually exclusive, and demand of the self-constituting African to negotiate their meeting point in a manner that is not culturally abrasive. This has led to Mphahlele appealing in the essay "Colonial conquest and its impact on African culture": "Let us not despise the followers of Lekganyane, Modise, Shembe and their kind [...] [because] the kind of self-abandon and joy they can express in their groups fulfil a hunger for contact with the Higher Power through direct contact with the ancestors, through their own body language and song; through a communally-shared religious experience free of intellectual sermonizing" (Mphahlele 2004: 255). The African independent churches meet his approval because their mode of worship is Afrikan Humanist.

One of the central building blocks of Afrikan Humanism, according to Mphahlele, is a sort of postcolonial hybridity in which traditional African religious tenets refuse to die. Similarly, because colonisation came with western Christianity, the imported trope of Christianity from the European colonisers remains one of the major features of religious practice among Africans today. According to him, the immensity of the challenge faced by Africans to manage postcolonial hybridity in an empoweringly self-defining manner is evident in divisions among Africans in the extent to which they embrace western Christianity and other imported lifestyles in an uncritically mimicking manner. Father Come Home is one of Mphahlele's novels in which the intersection of these two conflicting religions and its effects on African communities is explored in artistically and theoretically dexterous ways.

In the excerpt of a critique of Father Come Home below, the religious double loyalty in the characters is illustrated in interesting ways that testify both to the survival of an Afrikan Humanist consciousness and a cultural-religious ambivalence that leaves many Africans alienated with their true inner selves. It is Mphahlele's belief that a cultural identity that is preoccupied with menaces posed by people of a foreign, even conflicting mores would compromise living its own identity to the full. That is why he charts the way Africans should go about their self-definition during apartheid as follows in his essay "South African Literature versus the political morality":

I am never allowed to forget the high-voltage fences, so I have to create my own myth about survival, about the collective memory that orchestrates the human 
drama here. This is not a fantasy because ghetto life, urban and rural, does move as if it were independent of the fences, of the booby traps, of the brooding fate. The myth I endeavour to establish is that this part of our South African humanity will yet outlast at least some of the malicious gods, even when these have been replaced by another pantheon. (Mphahlele 2002: 374, original emphasis)

The malicious gods hinted in this 1983 essay are the imperialist cultural enforcements by oppressive rulers during apartheid. More significantly, Mphahlele concedes that blacks' suffering of the time under apartheid might be followed by yet one imperialist regime after another, yet the distinctive African identity, including their traditional religious consciousness will survive. He shares the conviction with writers like Stuart Hall when he stresses that "A national culture is the whole body of efforts made by a people in the sphere of thought to describe, justify and praise the action through which the people has created itself and keeps itself in existence" (Hall 1994: 403, emphasis added). Mphahlele admits that African identity can't survive through the passage of time totally unaffected by inevitable hybrid sensibility. His reference commonly to black urban and rural life as "ghetto" life reveals his unbelief in the interpretation by some theorists, of superficial social differences between urban and rural blacks as a symptom of the total loss of an underlying common African identity. Mphahlele's position is consolidated by a tenet of his philosophy of Afrikan Humanism expressed as follows: "Whatever happens, human life must survive as a collective or communal force (Mphahlele 2002: 138, emphasis added).

Mphahlele's continued creation of perspective by means of myth, in Father Come Home, consistently serves to debunk apartheid as ephemeral, in contrast with the heroic endurance of the life of blacks in South Africa that is ascribed to their varied lifestyles collectively defined as Afrikan Humanist (Rafapa 2006). Analysis of the novel also testifies that, in terms of Mphahlele's Afrikan Humanism which this novel seeks to exemplify, both blacks and whites can be African. As such, he does not define Africanness in racist terms that hinge on skin pigmentation. It is consciousness that he recognizes as one of the criteria qualifying one as an African, so that many whites may be African in consciousness while many blacks are not, despite their deceptive outward behaviour.

\section{Two axes of religion in the novel and their consequences on the life of Africans}

When the characters Hunadi and Dineo in Father Come Home resolve a petty quarrel one day, the latter responds to the former's apologies by appealing for harmony that will "let the ancestors sleep in peace and not be disturbed by words that stab like a spear" (Mphahlele 1984b: 48). Mphahlele in his essay "Notes towards an introduction to African Humanism: a personal enquiry" has indicated the Afrikan Humanist prac- 
tice of talking over differences until they are resolved. Disturbance of one segment of the order leads to disruption of harmony and this includes disturbing the peace of the ancestors. This could lead to punishment by the gods (Mphahlele 2002: 138). It is for this reason that, while pondering over the man Eliyase's mean temperament played out in his flogging of the protagonist young boy Maredi, the woman characters Dineo and Hunadi reassure each other that Eliyase's wife does not bear children because "it is punishment" of Eliyase by "the ancestors" for his failing to bring together the Tulamo family as the only man remaining (Mphahlele 1984b: 11). Maredi has grown up in a family headed by the mother Dineo, because his father went to work in Johannesburg and never returned. Hunadi is the wife of Maredi's paternal uncle who has also been swallowed up by Johannesburg. Eliyase, as a brother of the two men who have vanished, thus is culturally expected to take the responsibility of piecing together the extended Tolamo family. But the two women's remarks expose him for a man who does not live up to their and their community's expectations as dictated by folklore.

The two axes of religion within African characters spawned by hybridity that comes along with an encounter with the West take on bolder contours in Father Come Home. This has led Obee (1999: 207) to describe this phenomenon as portrayed in this novel in grand terms that almost equal the totality of the African experience:

Mphahlele's discourse on conflict between Christians and 'heathens' gives him the opportunity to outline African humanist precepts such as the belief in a Supreme Being, "whose presence they felt where human relations were harmonious" and the belief in ancestors who "were always living and present to guide them into the paths of decency, of goodness, of harmony among people." He notes that people of Mashite "prayed to the Supreme Being through the ancestors, without assembling for the express purpose of praying."

Maredi's uncle, Eliyase, beat him up severely for venturing into a bush belonging to the Mashite section of the village whose inhabitants are shunned for their "heathenness". The Tulamo family to which the protagonist belongs is on the Christian side of the village called Sedibeng. Maredi having just awakened from childhood innocence finding himself belonging to the "Christian" side does not really have his own reasons not to regard the 'heathens' as fellow men worth interacting with. The two women Dineo and Hunadi are "Christians". Yet they invoke ancestors in their private criticism of Eliyase's brutal beating of the boy Maredi for the mere reason that he entered 'heathen' territory out of curiosity. Actually, the beating nearly killed the boy. Dineo and Hunadi's censure of Eliyase's attitude and action are consonant with what another African writer of the 1950s asserts:

In the communal culture of my ancestors which still governs our lives, we all share the same blood, and the taking of it, even in the execution of justice, is condemned as an uncivilised ritual [...] Moshoeshoe, the paramount chief of Basutoland, in- 
stead of raining his vengeance on the derelict army which had eaten his father, sent down from his mountain fortress a herd of cattle to the cannibal army with the message that he could not desecrate the graves of his father. (Modisane 1963: 54)

Bloke Modisane's confession to believing in ancestors is significant in two major respects. First he is one of the urban blacks of the fifties in Sophiatown, whom some writers such as Chapman (2001: 201,204) believed were "detribalized", meaning the urban environment had purged them of their (backward) traditional ways. Secondly, a reading of his autobiography Blame Me on History attests that he grew up in a civilised, Christian family. It is thus symptomatic of a hybridised religious orientation for him, much as the woman characters, to invoke ancestral intervention in human affairs.

A similar regard for ancestors is sustained as the storyline develops. Following Maredi's exploration of the forbidden bush, as Dineo and Hunadi exchange greetings the following morning, Hunadi complains of insomnia and an indistinct malaise. She attributes the restlessness overnight to ancestors who "travel in the night and visit [her] dreams and [do] not speak so that [she] can hear". She concludes by exclaiming in Sesotho sa Leboa, "Ao, what wonders!" (Mphahlele 1984b: 46) In this nightmare that forebodes her own death, Hunadi exhibits the Afrikan Humanist view that ancestors communicate with the living on any important matter in order for wrongs to be atoned where possible. When shortly Hunadi dies, Dineo explains to Maredi that "life without [one's] man is very heavy" and that the heart sore longing must have killed her (Mphahlele 1984b: 74). The indistinct message of her dreams referred to above is unravelled as having been a message too difficult to understand and unnecessary to understand, as her impending death is depicted as inevitable through the way Dineo rationalises it. Hunadi herself must be sensing the content of the ancestors' message when she exlaims by means of the Sotho colloquialism " $A o^{\text {", }}$ which signifies bafflement. Unlike the way African language colloquialisms have been used by characters in both rural and urban settings to express personal feelings of excitement, sorrow, wonderment and so forth in Mphahlele's other works, in Father Come Home colloquialisms such as this convey prophetic messages that are pointers for the entire tribe or nation. As Mphahlele's concept of Afikan Humanism accentuates one distinguishing feature between Africans and Europeans as the communal lifestyle of Africans, this Afrikan Humanist tenet is thus vindicated by such use of dialogue in the novel.

That is why in the quotation above, Hunadi's dialogue at the point when it reaches the Sotho colloquial exclamation, acquires a plane beyond that of focusing on the dream and foretells her death by words that suggest its inscrutability: "what wonders!" It is because she has reached a point beyond which the human mind can fathom, because this is the meeting point of her own prophetic voice with that of the village sage Mashabela, when the latter proclaims that "The land is gone,/ and all that 
has been left for us / is grey sand and rock / We walk with death in our legs, / with famine and with locusts" (Mphahlele 1984b: 21). Here the individual rises into the communal and epic, soaring too high for an individual mind to tame. In typical Africanist premise, by creating a character like Mashabela, Mphahlele concurs with Soyinka's (1976: 67) perception that "African writing is [...] rooted in the concept of literature as part of the normal social activity of man". Apart from an illustration of this in Father Come Home, in black African life today oral literary forms are not the preserve of individuals but every member of the community participates in themsuch as praise singing, ritual singing during cultural practices of initiation and dancing in groups expected by lore to perform in certain traditional ceremonies.

The important point to remember is that Mphahlele's depiction of rural African life in modern times explores a self-contained African lifestyle that abides despite apartheid dictating life in South Africa. The reader is reminded of the persistence of apartheid conditions not only by portrayal of the men who are dislocated from their families in order to fit in apartheid's matrix of the migrant labourer. But as it is the hybridity of religion that the author is bent to foreground in this section of the novel, the ambience of apartheid is only hinted at as a backdrop to the central drama of the book. It is only towards the end of the book where Mphahlele reminds the reader of apartheid's presence, as if to express satisfaction that he has succeeded in unfurling the depiction of Afrikan Humanist life despite apartheid existing alongside it.

When many decades later Mashabela's aged daughter (Batseba) meets the 72-yearold Maredi at a wedding in Seshego and the two discuss the rumoured forced removal of Sedibeng and nearby villages to the west, uppermost in Maredi's mind is concern over what will happen to the graves of their ancestors, especially those of Mashabela, Tintina and Hunadi (Mphahlele 1984b: 96). Tintina is a mentally deranged character who left for the mines in Johannesburg but returned a numskull while both Batseba and Maredi were still children, after being ruined by conditions concomitant to dehumanising conditions in mining compounds. The old man Maredi Tulamo laments forced removals in the following emotive words: "I have seen enough sorrow in my life to blind the sun, when old people have to keep moving, leaving their land - land they have known and loved - moving to strange places, dragging behind them their souls, looking baffled and lost, leaving the burial grounds of their loved ones" (Mphahlele 1984b: 97). The enumeration of people who have been intimate with Batseba and Maredi in this dialogue precedes the mention of the people's graves in general. Attachment to home soil is suggested by means of such an intimate familiarisation of the graves Sedibeng people are about to be forcibly separated with. The anguish experienced by Africans is immense, due to their valuing of ancestral connection for which graves are the medium, whenever forced removals separate them from these shrines. This anguish is expressed powerfully by means of the phrase "dragging behind them their souls", which explains the strong, unbreak- 
able bond between Africans and their ancestral land. Closure of the novel with this disturbing image of a people ever on the move is Mphahlele's way of highlighting that even as he returns home in his old age and is gratified by the way the rural, African-cultural milieu facilitates self-fulfilment in being useful to one's people, the horror of apartheid is still part of his people's "unbroken song". He published this book in 1984 after returning from physical exile that started in 1957. Merging of the plot of the novel with Mphahlele's biographical detail is justifiable, because most of the content of his novels is autobiographical in nature (Rafapa 2006).

Connectedness with relatives who have died as demonstrated in the lives of the characters portrayed above, is Mphahlele's way of representing a consciousness he calls Afrikan Humanism (Rafapa 2006). Ancestral connections are one of the many religious aspects of Mphahlele's concept. Witchcraft is another, although usually perceived as negative and mentioned by African writers as one item of the African heritage that must be abandoned. To create resonances of this shameful and thus clandestine tradition, Mphahlele assembles a medley of gossip regarding the Mashite bush (nicknamed Sotoma after the Biblical Sodom and Gomorrah parable) in the following words: "We have always been told those people kill a man or child and take out parts of the body to give to the ancestors [...] Madira the grandmother of Tintina, as the people tell us, told the village that she saw a woman on a baboon come out of the woods one night" (Mphahlele 1984b: 39). So reminiscent of communal tap gossip in Down Second Avenue (1959), the quotation above reinforces the "positive face" or "politeness" wants within African cultures which determine the desirability of expressed messages aligning with communally-agreed standpoints. Bruce Fraser (1990) and Yoshiko Matsumoto (1988) have defined the ideas of "face" or "politeness" wants as differing according to specific cultures. Mphahlele's deliberate removal of the identity of the speakers in this passage is an indication that these messages are not attributable to single individuals, but are a communal verdict. This is why not one character in all of Mphahlele's oeuvre has been quoted as challenging the opinion that witchcraft is evil.

When the sage Mashabela rebukes his neighbours in Sedibeng for denigrating the sacredness of the Mashite bush, it is not witchcraft he is defending. Being an African, there is no way Mashabela can oppose the community in traditionally agreed-upon opinion about some practices. What he is standing up against is the unwise, licentious heaping of all conceivable insults on the bush by "Christian" Africans for the mere reason that the bush is holy ground for "heathen" Africans. Mashabela publicly declares what he is sure to be right in the following words (that echo the wisdom of Old Segone in Mphahlele's Down Second Avenue on a similar division of the two sections of Maupaneng):

Hear me, listen to me, you people [...] we must not play about with things that our small brains cannot understand simply because you think God is only on your side and against the others. That place you call Sotoma is holy ground for the people of 
Mashite, and all of us are children on the small finger of God whom our ancestors knew well, to whom they speak for us. (Mphahlele 1984b: 40)

While the message echoes that of the sage character in Down Second Avenue, also on the "Christian" side of the village, for the first time in his fiction Mphahlele lets a character speak in an overtly prophetic tone as the words "hear me, listen to me, you people" indicate (Rafapa 2006).

With the concept of Afrikan Humanism allowed to materialise in the carnal form of Mashabela, it is not surprising that western Christianity acquires a human voice through the mouth of the lay preacher in Sedibeng, who routinely bellows antidotes to Mashabela's "darkness" in the following words:

Listen not to creatures of darkness who pull you away to their heathen gods [...] The new Christ is come among us and I hear His words tell us to turn away from our ancestral ways, to touch the scars of the Crucifixion and be healed, be cleansed of our sins. Those poor souls of Mashite over there - I pity them, and let us pray that Sotoma, like the city of its name in the Bible, shall be razed to ashes even as Gomorrha was [...] The white man brought the light and we can read and write for ourselves and that knowledge and light mean power and the road to salvation. (Mphahlele 1984b: 40-41)

Comparably to the way in which Afrikan Humanism is sung openly by the character Mashabela in a "compelling voice", the lay preacher is also reciting "with his stentorian voice" to the Africans - but here it is a gospel that preaches everything which Afrikan Humanism is not (Mphahlele 1984b: 20, 40). It is not surprising, within the deeply rural and traditional environment of Sedibeng, for the lay preacher to speak almost like a ventriloquist with a voice that the soul cannot quite identify with because, being black, he is either hollow as far as self-knowledge is concerned or he is a mere marionette of the champions of a consciousness opposed to Afrikan Humanism. This lay preacher is a far cry from the Zionist self-constituting worshipper to whom Mphahlele's other works have introduced us. A passage in Down Second Avenue describes the innovative handling of western Christianity by breakaway leaders in Marabastad like the "prophet" in the Donkey Church (Mphahlele 1959: 99-100). The activities of such religious leaders appear to excite Mphahlele due to their abrogation of the white man's religion in such a fashion that it actually promotes and ensures economic and spiritual survival.

The lay preacher's words, which are devoid of the self-defining vigour that drives Zionist preachers as in the example cited from Down Second Avenue, are akin to the way Eliyase "who [is] so loud about being a Christian" writes off the boy Maredi: "He was always carrying on about Maredi's heathen habits: shouting in the streets, singing nonsense lyrics in the homestead and blowing a whistle at intervals" and: "He always 
spoke about Maredi as if the boy would one day, soon, release devastating thunder and hail and lightning that would flatten Sedibeng and the vast territory around" (Mphahlele 1984b: 41,42). The intimations of damnation in hell created by images in the passage above conflict with Afrikan Humanism in the way Mphahlele describes it in the essay "The fabric of African culture and religious beliefs" as composed of "beliefs [that] do not entertain punishment or reward in the after-life" (Mphahlele 2002: 154).

Dialogue in this novel conjures up an Afrikan Humanist atmosphere by means of traditional resonances accomplished through orature. This stylistic aspect weaving through all of Mphahlele's narrative writings is deepened to the level of mythmaking that merges the private conflict and self-actualising action of the protagonist Maredi with the epic odyssey of a mythical son whose heroism rids the nation of the shackles of urbanisation, apartheid and colonisation. Sotho proverbs and idiomatic expressions slip readily into the texture of the dialogue to signify the harmony of protagonists and antagonists who are tied together at the underlying level by Afrikan Humanist consciousness and differ only in some facets of their surface behaviour. It is in these folklore resources that an Africanist consciousness is preserved to the best, within the idioms of the indigenous languages. The colloquialisms Mphahlele has been constantly employing in his other works of fiction perform in this novel a more profound function than expression of private feelings and the adding of dramatic naturalness to dialogue. In Father Come Home colloquial expressions mark decisive transitions in the action of the central character, which coincides with similarly momentous forward movements in the emancipation of a whole people. The fact that such epic pronouncements are made within a spiritual terrain contested by western Christianity and traditional African religions is indicative of the central role religion plays in the lives of both the "Christian" Africans of Sedibeng and "heathen" ones of Mashite.

\section{Conclusion}

This novel helps to highlight a crisis of consciousness faced by the formerly colonised in the postcolonial period. The centralising, in Father Come Home, of religious hybridity obtaining today among Africans is an indication also, of the way Mphahlele regards religion as pervading the day-to-day life of Africans.

The concept of Afrikan Humanism as defined by Mphahlele is helpful in understanding the characterisation, images and dialogue in an exhaustive way. Afrikan Humanism is a potent tool that could be used to analyse not only Mphahlele's fiction, but any Afrocentric work by the postcolonial writer of fiction.

This is demonstrated in the way citations of Mphahlele's Afrikan Humanist orientations revealed by the expository and narrative works discussed in this article helped me analyse the intricate co-existence of opposing religious pulls in this novel. When read outside the frame of reference of Afrikan Humanism this novel deceptively 
appears to be lacking in thematic profundity and stylistic texture. Even so outstanding a theme such as the two religious axes informing the postcolonial African consciousness could be under-interpreted as a mere strategy to effect the element of conflict in the dramatic unfolding of the novel.

\section{Note}

1. In all his expository writing Mphahlele spells the word as "African humanism" and in my initial critical writing on his theory I followed his example since I regarded it as an attempt at describing this concept as a bridge meant to temper polarity between those who might agree and those who might differ. Since my initial work some South African scholars started acknowledging Mphahlele's theory of Afrikan Humanism as a distinctive consciousness and way of life, rather than an exaggeration of a facet of Western humanism. To mark acceptance of such distinctiveness the current spelling -Afrikan Humanism - is preferred; the abandonment of the Westernized spelling of Africa should highlight the independence of this theory from European thought.

\section{Works cited}

Ashcroft, B., Griffiths G., Tiffin, H. 1989. The Empire Writes Back. New York: Routledge.

Attwell, D. 1999. Fugitive Pieces: Es'kia Mphahlele's The Wanderers: A Novel of Africa. Current Writing 11(2): 67-73.

Chapman, C. 2001. The Drum Decade. Stories from the 1950s. Pietermaritzburg: University of Natal Press.

Chatterjee, P. 1993. The Nation and Its Fragments. Colonial and Postcolonial Histories. New Jersery: Princeton University Press.

Fanon, F. 1963. The Wretched of the Earth. London: Penguin Books.

Fraser, B. 1990. Perspectives on politeness. Journal of Pragmatics 14(2): 219-236.

Hall, S. 1994. Cultural Identity and Diaspora. In Patrick Williams and Laura Chrisman (eds.). Colonial Discourse and Post-colonial Theory. Hertfordshire: Prentice Hall, 392-403.

Kudadjie, J. and Osei, J. 1988. Understanding African Cosmology: Its content and contribution to worldview, community and the development of science. Faith, Science and African Culture. Pretoria: Unisa, 33-64.

Loomba, A. 1998. Colonialism/Postcolonialism. London and New York: Routledge.

Manganyi, N. C. 1983. Exiles and Homecomings. A Biography of Es'kia Mphahlele. Johannesburg: Ravan Press.

Matsumoto, Y. Reexamination of the Universality of Face: Politeness Phenomena in Japanese. Journal of Pragmatics 12(1): 403-426.

Modisane, B. 1963. Blame Me On History. London: Thames and Hudson.

Mphahlele, E. 1947. Man Must Live and Other Stories. Cape Town: African Booksellers. 1959. Down Second Avenue. London: Faber and Faber.

1971. The Wanderers. New York: The Macmillan Company.

1979. Chirundu. Johannesburg: Ravan Press.

1984a. Afrika My Music. Johannesburg: Ravan Press.

1984b. Father Come Home. Johannesburg: Ravan Press.

2002. Es'kia. Cape Town: Kwela Books; Johannesburg: Stainbank \& Associates.

2004. Es'kia Continued. Johannesburg: Stainbank \& Associates.

Obee, R. 1999. Es'kia Mphahlele: Themes of Alienation and African Humanism. Athens: Ohio University Press.

Rafapa, L. J. 2006. The Representation of African Humanism in the Narrative Writings of Es'kia Mphahlele. Johannesburg: Stainbank \& Associates.

Said, E. 1990. Yeats and Decolonization. Nationalism, Colonialism and Literature. Minneapolis: University of Minnesota Press, 69-95.

Samin, R. 1998. Interview: Richard Samin with Eskia Mphahlele. Research in African Literatures 34(1): 182-200.

Soyinka, W. 1976. Myth, Literature and the African World. Cambridge: Cambridge University Press.

Woeber, C. 2001. The Influence of Western Education on South Africa's First Black Autobiographers. English Studies in Africa 44(2): 57-71. 